\title{
Feeding habits of the blue shark (Prionace glauca) off the coast of Brazil
}

\author{
Teodoro Vaske Júnior ${ }^{1,3}$, Rosangela Paula Lessa ${ }^{2}$ \& Otto Bismarck Fazzano Gadig ${ }^{1}$ \\ ${ }^{1}$ Departamento de Biologia Marinha, Universidade Estadual Paulista - UNESP, \\ Praça Infante Dom Henrique, s/n, CEP 11330-900, São Vicente, SP, Brazil \\ ${ }^{2}$ Departamento de Pesca, Universidade Federal Rural de Pernambuco - UFRPE, \\ Dois Irmãos, CEP 52171-900, Recife, PE, Brasil \\ ${ }^{3}$ Corresponding author: Teodoro Vaske Júnior, e-mail: vaske@ig.com.br
}

VASKE Jr., T., LESSA, R.P. \& GADIG O. B. F. Feeding habits of the blue shark (Prionace glauca) off the coast of Brazil. Biota Neotrop. 9(3): http://www.biotaneotropica.org.br/v9n3/en/abstract?article+bn00809032009.

\begin{abstract}
Stomachs from 222 blue sharks collected along the Brazilian coast were analyzed - 116 from the northeastern region and 106 from the southern region. A total of 51 prey taxa were identified. The most important prey items in the southern region were Mysticeti whales, teleosteans, the gempylid Ruvettus pretiosus and the nomeid Arioma bondi. Cephalopods were more diverse, with dominance of vertical migrants Histioteuthis spp., Cranchiidae and the epipelagic octopus Ocythoe tuberculata. In the northeastern region, blue sharks consumed mainly teleosteans, including the alepisaurid Alepisaurus ferox and the gempylid Gempylus serpens. Among cephalopods, Histioteuthis spp. and the epipelagic octopus Tremoctopus violaceus were the dominant items. Predation upon schooling prey was occasional, as observed on Arioma bondi. Birds also were consumed in both regions; Puffinus gravis was the fifth most frequent item in the northeastern region. During the reproductive migration cycle, blue sharks likely prey in the thermocline, which is deeper in the northeastern region and closer to the surface in the southern region.
\end{abstract}

Keywords: Elasmobranch, Carcharhinidae, diet.

VASKE Jr., T. , LESSA, R. P. \& GADIG O. B. F. Habito alimentar do tubarão-azul (Prionace glauca) da costa do Brasil. Biota Neotrop. 9(3): http://www.biotaneotropica.org.br/v9n3/pt/abstract?article+bn00809032009.

Resumo: Estômagos de 222 tubarões-azuis coletados ao longo da costa brasileira foram analisados, sendo 116 da região nordeste e 106 da região sul. Um total de 51 táxons de presas foram identificados. Os itens mais importantes na região sul foram baleias Mysticeti, teleósteos, o peixe gempilídeo Ruvettus pretiosus e o nomeídeo Arioma bondi. Cefalópodes foram mais diversos, com preferência pelas espécies migradoras verticais Histioteuthis spp., Cranchiidae e o polvo epipelágico Ocythoe tuberculata. Na região nordeste, o tubarão-azul consumiu principalmente teleósteos, incluindo o peixe alepisaurídeo Alepisaurus ferox e o gempilídeo Gempylus serpens. Entre os cefalópodes, Histioteuthis spp. e o polvo epipelágico Tremoctopus violaceus foram os itens principais. Predação sobre cardumes foi ocasional, como observada para Arioma bondi. Aves também foram consumidas em ambas as regiões. Puffinus gravis foi o quinto item mais freqüente na região nordeste. Durante o ciclo migratório reprodutivo, o tubarão-azul costuma predar nas adjacências da termoclina, que é mais profunda na região nordeste e mais perto da superfície na região sul.

Palavras-chave: Elasmobranch, Carcharhinidae, dieta. 


\section{Introduction}

The blue shark (Prionace glauca) is the only species of the genus Prionace and belongs to the family Carcharhinidae, collectively known as requiem sharks (Compagno 1984). Blue sharks are found worldwide in temperate and tropical oceans, most often in offshore surface waters (Compagno 1984). They are normally characterized as opportunistic feeders and are reported to eat a wide variety of prey, including bony fish, squids, birds and marine mammal carrion (Cortés 1999). Blue sharks are the most heavily fished species of sharks in the world, which is the single largest source of adult mortality, where it was assessed as near threatened (IUCN 2008).

The species prefers offshore habitats, but has occasionally been observed inshore waters. Since 1990, the blue shark CPUE (capture per Unit of Effort) of the Brazilian fleet based in Natal (RN) has generally been about one-third of the values obtained from southeastern Brazil, confirming the increase in the abundance of the species with latitude (Amorim et al. 2002, Azevedo et al. 2003, Hazin \& Lessa 2005). Due to its high proportion in commercial longline catches around the world, blue shark is a well-studied species with regard to distribution and migration. There is information on its diet around the world, with feeding biology studies carried out for the Indian Ocean (Gubanov \& Grigoryev 1975), California (Tricas 1979, Harvey 1989), the Gulf of Alaska (Le Brasseur 1964), the Southwestern Equatorial Atlantic (Hazin et al. 1994), the Bay of Biscay, English Channel (Clarke \& Stevens 1974) and Ireland (Macnaughton et al. 1998). However, little is known on its feeding habits in the South Atlantic. There are only two references for Brazilian waters - one for the Index of Relative Importance (IRI) in the southern region (Vaske Jr. \& Rincon Fo. 1998) and another for a prey list in the northeastern region (Hazin et al. 1994). The aim of the present study was to compile past and present results on stomach contents from the southern and northeastern regions, comparing the diets from both regions.

\section{Material and Methods}

The study area corresponds to the main area of longline operations in Brazilian waters, i. e., from $30^{\circ}$ to $40^{\circ} \mathrm{W}$ and $1^{\circ} \mathrm{N}$ to $9^{\circ} \mathrm{S}$ (northeastern region-NE) and from $40^{\circ}$ to $50^{\circ} \mathrm{W}$ and $25^{\circ}$ to $35^{\circ} \mathrm{S}$ (southern region-S) (Figure 1). Sampling was carried out between October 1992 and December 1999 in the northeastern region and from March 2007 to March 2008 in the southern region. Blue sharks were caught by tuna longliners baited with sardine, mackerel and squid. The sharks were retrieved onboard and the stomachs removed, severing the abdominal cavity from the intestine to the esophagus when the fish was gutted. Stomachs were preserved frozen onboard and analyzed in the laboratory. Total length $(\mathrm{cm})$, local position and date of capture were recorded. Stomach content was considered to be the material retained in a 1-mm mesh sieve. Stomach fullness was recorded based on a five-point scale estimated as percentage of total fullness: empty, $25 \%$ full, $50 \%$ full, $75 \%$ full, and full.

The importance of each food item in the diet was obtained by the Index of Relative Importance (IRI) (Pinkas et al. 1971), modified for weight in the pooled samples of the species (Equation 1):

$$
\mathrm{IRI}_{\mathrm{i}}=\% \mathrm{FO}_{\mathrm{i}} \times\left(\% \mathrm{~N}_{\mathrm{i}} \times \% \mathrm{~W}_{\mathrm{i}}\right)
$$

in which $\% \mathrm{FO}_{\mathrm{i}}$ - relative frequency of occurrence of each item; $\% \mathrm{~N}_{\mathrm{i}}$ - proportion in prey number of each item in the total; and $\% \mathrm{~W}_{\mathrm{i}}$ - proportion in weight of each item in the total.

Similarity between diets in the southern and northeastern regions was calculated by the the MacArthur and Levins measure with Pianka's symmetric modification (Krebs 1989) (Equation 2) :

$$
\mathrm{O}_{\mathrm{jk}}=\Sigma \mathrm{p}_{\mathrm{ij}} \mathrm{p}_{\mathrm{ik}} / \sqrt{ }\left(\Sigma \mathrm{p}_{\mathrm{ij}} \Sigma \mathrm{p}_{\mathrm{ik}}\right)
$$

in which: $\mathrm{O}_{\mathrm{jk}}=$ MacArthur-Levins measure for resources $\mathrm{j}$ and $\mathrm{k}$ (regions); $\mathrm{p}_{\mathrm{ij}}=$ Resource proportion $\mathrm{i}$ is of the total resources used by species $j ; p_{i k}=$ Resource proportion $i$ is of the total resources used by species $\mathrm{k}$.

\section{Results}

A total of 222 stomachs from blue sharks along the Brazilian coast were analyzed -116 from the northeastern region 106 from the southern region. Total lengths were obtained for 84 blue sharks in the northeast and 79 blue sharks in the south (Figure 2).

A total of 51 prey taxa were identified including 20 species of fishes, 24 cephalopods, two crustaceans and five other groups (Table 1). The most important prey items in the southern region were Mysticeti whales and teleosteans, including the gempylid Ruvettus pretiosus and the nomeid Arioma bondi. Cephalopods were more diverse, with a dominance of the vertical migrants Histioteuthis spp., Cranchiidae and the epipelagic octopus Ocythoe tuberculata. In the northeastern region, blue sharks consumed mainly teleosteans, such as the alepisaurid Alepisaurus ferox and the gempylid Gempylus serpens. Among cephalopods, Histioteuthis spp. and the epipelagic octopus Tremoctopus violaceus were the main items. Predation upon schools was occasional, as observed with the nomeid Arioma bondi, where 172 individuals in fresh conditions were found in only two full stomachs from the same site in the south. Birds also occurred in both regions; Puffinus gravis was the fifth most frequent item in the northeastern region. The main prey item in the south was Mysticeti whale, found in multiple chunks in eleven stomachs, which suggests predation upon dead individuals, which are more frequent at higher latitudes.

Prey richness was higher in the southern region, where 40 taxa were identified (15 species of fish, 20 cephalopods, two crustaceans

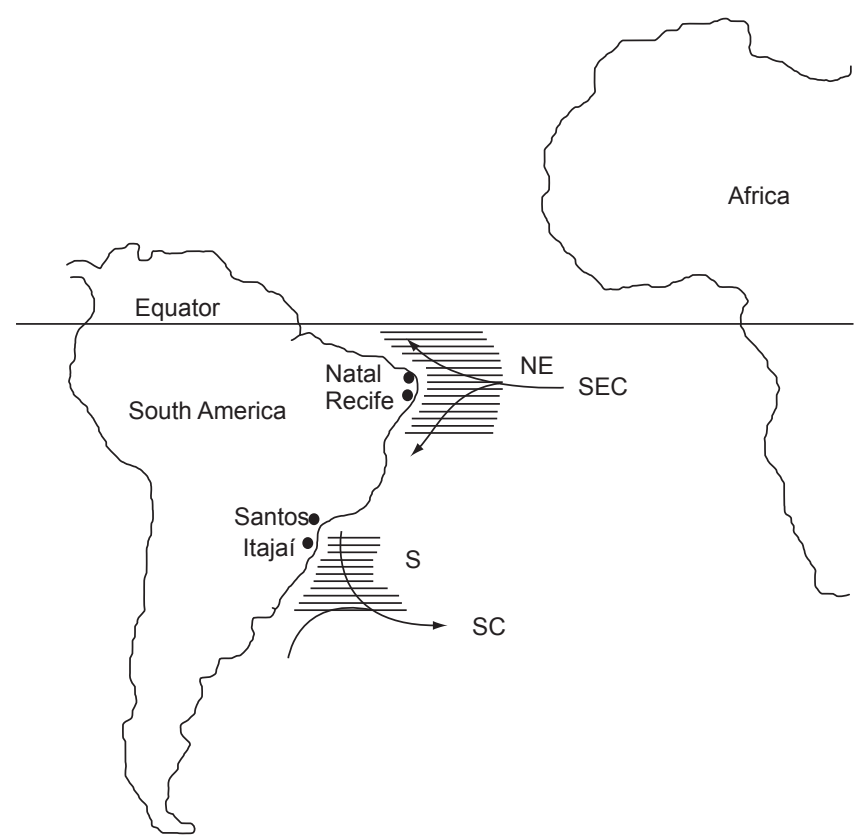

Figure 1. Sample areas (shaded), where stomachs from Prionace glauca were collected in the southern (S) and northeastern (NE) regions, with respective landing harbors. Arrows indicate the main flows: SEC - South Equatorial Current; SC - Subtropical Convergence.

Figura 1. Áreas amostradas (sombreadas), onde os estômagos de Prionace glauca foram coletados nas regiões sul (S) e nordeste (NE), com os respectivos portos de desembarque. As setas indicam as principais correntes: SEC - Corrente Sul equatorial; SC - Subconvergência tropical. 
Feeding of the blue shark

Table 1. Percentages in number, weight and frequency of occurrence of food items for Prionace glauca in the northeastern (NE) and southern (S) regions. IRI from the most important item (1) to the tenth most important item (10).

Tabela 1. Porcentagens em número, peso e frequência de ocorrência de itens alimentares para Prionace glauca nas regiões nordeste (NE) e sul (S). IRI varia do item mais importante (1) até o décimo em importância (10).

\begin{tabular}{|c|c|c|c|c|c|c|c|c|c|c|c|c|c|c|}
\hline Food items & $\mathbf{N S}$ & $\begin{array}{c}\% \\
\text { NS } \\
\end{array}$ & P S & $\begin{array}{c}\% \\
\text { P S } \\
\end{array}$ & $\begin{array}{c}\text { FO } \\
\text { S } \\
\end{array}$ & $\begin{array}{c}\% \\
\text { FOS } \\
\end{array}$ & $\begin{array}{c}\text { IRI } \\
\mathrm{S} \\
\end{array}$ & $\begin{array}{c}\mathbf{N} \\
\mathbf{N E} \\
\end{array}$ & $\begin{array}{l}\% \mathbf{N} \\
\mathrm{NE} \\
\end{array}$ & $\begin{array}{c}\mathbf{P} \\
\mathbf{N E} \\
\end{array}$ & $\begin{array}{c}\% \\
\text { PNE } \\
\end{array}$ & $\begin{array}{l}\text { FO } \\
\text { NE } \\
\end{array}$ & $\begin{array}{c}\% \mathrm{FO} \\
\mathrm{NE} \\
\end{array}$ & $\begin{array}{l}\text { IRI } \\
\text { NE }\end{array}$ \\
\hline Alepisaurus brevirostris & 3 & 0.68 & 425 & 1.02 & 3 & 4.17 & & & & & & & & \\
\hline Alepisaurus ferox & & & & & & & & 7 & 3.61 & 2798 & 11.87 & 7 & 8.64 & 2 \\
\hline Arioma bondi & 172 & 39.0 & 1217 & 2.91 & 2 & 2.78 & 4 & & & & & & & \\
\hline Brama brama & & & & & & & & 1 & 0.52 & 5 & 0.02 & 1 & 1.23 & \\
\hline Caranx sp. & 20 & 4.4 & 298 & 0.71 & 1 & 1.39 & & 1 & 0.52 & 163 & 0.69 & 1 & 1.23 & \\
\hline Decapterus sp. & 1 & 0.23 & 875 & 2.09 & 1 & 1.39 & & & & & & & & \\
\hline Diaphus sp. & & & & & & & & 1 & 0.52 & 4 & 0.02 & 1 & 1.23 & \\
\hline Diodon hystrix & & & & & & & & 3 & 1.55 & 164 & 0.70 & 4 & 4.94 & 10 \\
\hline Gempylus serpens & 3 & 0.68 & 371 & 0.89 & 3 & 4.17 & & 19 & 9.79 & 39 & 0.17 & 3 & 3.70 & 8 \\
\hline Lamna nasus & 1 & 0.23 & 4034 & 9.65 & 1 & 1.39 & & & & & & & & \\
\hline Lampris guttatus & 2 & 0.45 & 3213 & 7.69 & 2 & 2.78 & 9 & & & & & & & \\
\hline Monacanthidae & 8 & 1.81 & 304 & 0.73 & 1 & 1.39 & & & & & & & & \\
\hline Myctophidae & 1 & 0.23 & 3 & 0.01 & 1 & 1.39 & & & & & & & & \\
\hline Pteroplatytrygon violacea & 1 & 0.23 & 96 & 0.23 & 1 & 1.39 & & & & & & & & \\
\hline Ruvettus pretiosus & 4 & 0.91 & 2544 & 6.09 & 4 & 5.56 & 7 & & & & & & & \\
\hline Tetrapturus pfluegeri & & & & & & & & 1 & 0.52 & 7500 & 31.83 & 1 & 1.23 & 7 \\
\hline Teleostei & 50 & 11.34 & 735 & 1.76 & 11 & 15.28 & 3 & 57 & 29.38 & 2407 & 10.21 & 23 & 28.40 & 1 \\
\hline Thunnus sp. & 1 & 0.23 & 250 & 0.60 & 1 & 1.39 & & & & & & & & \\
\hline Trachypterus arawatae & 2 & 0.45 & 1124 & 2.69 & 2 & 2.78 & & & & & & & & \\
\hline Xiphias gladius & 2 & 0.45 & 2134 & 5.11 & 2 & 2.78 & & 1 & 0.52 & 150 & 0.64 & 1 & 1.23 & \\
\hline FISH & 271 & 61.45 & 17623 & 42.17 & & & & 91 & 46.91 & 13230 & 55.45 & & & \\
\hline Architeuthis sp. & 1 & 0.23 & 360 & 0.86 & 1 & 1.39 & & & & & & & & \\
\hline Cephalopoda & & & & & & & & 8 & 4.12 & 2210 & 9.38 & 7 & 8.64 & 3 \\
\hline Chiroteuthis spp. & 15 & 3.40 & 46 & 0.11 & 11 & 15.28 & 5 & 2 & 1.03 & & & 2 & 2.47 & \\
\hline Cranchiidae & 4 & 0.91 & 926 & 2.22 & 4 & 5.56 & 10 & 14 & 7.22 & 5 & 0.02 & 9 & 11.11 & \\
\hline Enoploteuthidae & 1 & 0.23 & & & 1 & 1.39 & & & & & & & & \\
\hline Gonatus sp. & 1 & 0.23 & & & 1 & 1.39 & & & & & & & & \\
\hline Haliphron atlanticus & 1 & 0.23 & 424 & 1.01 & 1 & 1.39 & & 6 & 3.09 & 18 & 0.08 & 5 & 6.17 & \\
\hline Histioteuthis spp. & 79 & 17.91 & 60 & 0.14 & 24 & 33.33 & 2 & 14 & 7.22 & 530 & 2.25 & 13 & 16.05 & 6 \\
\hline Hyaloteuthis pelagica & & & & & & & & 10 & 5.15 & 10 & 0.04 & 3 & 3.70 & \\
\hline Illex argentinus & 5 & 1.13 & 890 & 2.13 & 5 & 6.94 & 8 & & & & & & & \\
\hline Japetella diaphana & 3 & 0.68 & & & 2 & 2.78 & & 12 & 6.19 & & & 8 & 9.88 & \\
\hline Megalocranchia maxima & 1 & 0.23 & 360 & 0.86 & 1 & 1.39 & & & & & & & & \\
\hline Octopodidae & & & & & & & & 4 & 2.06 & & & 2 & 2.47 & \\
\hline Octopoteuthis sp. & 1 & 0.23 & & & 1 & 1.39 & & 1 & 0.52 & 2 & 0.01 & 1 & 1.23 & \\
\hline Ocythoe tuberculata & 4 & 0.91 & 2600 & 6.22 & 4 & 5.56 & 6 & 4 & 2.06 & 90 & 0.38 & 3 & 3.70 & \\
\hline Ommastrephes bartramii & 6 & 1.36 & 249 & 0.60 & 5 & 6.94 & & 2 & 1.03 & & & 2 & 2.47 & \\
\hline Ommastrephidae & 1 & 0.23 & & & 1 & 1.39 & & & & & & & & \\
\hline Onychoteuthidae & 3 & 0.68 & 174 & 0.42 & 3 & 4.17 & & & & & & & & \\
\hline Ornithoteuthis antillarum & 2 & 0.45 & 1 & & 1 & 1.39 & & & & & & & & \\
\hline Pholidoteuthis sp. & 4 & 0.91 & & & 1 & 1.39 & & & & & & & & \\
\hline Taonius pavo & 3 & 0.68 & 154 & 0.37 & 3 & 4,17 & & & & & & & & \\
\hline Tremoctopus violaceus & 5 & 1.13 & 788 & 1.89 & 4 & 5.56 & & 5 & 2.58 & 4373 & 18.56 & 5 & 6.17 & \\
\hline Thysanoteuthis rombus & & & & & & & & 1 & 0.52 & & & 1 & 1.23 & \\
\hline Vampyroteuthis infernalis & 1 & 0.23 & & & 1 & 1.39 & & & & & & & & \\
\hline CEPHALOPODS & 141 & 31.97 & 7032 & 16.83 & & & & 83 & 42.78 & 7238 & 30.72 & & & \\
\hline Caridae & 1 & 0.23 & 20 & 0.05 & 1 & 1.39 & & & & & & & & \\
\hline Platyscelidae & 1 & 0.23 & 1 & & 1 & 1.39 & & & & & & & & \\
\hline CRUSTACEANS & 2 & 0.46 & 21 & 0.05 & 2 & 2.78 & & & & & & & & \\
\hline Mysticeti & 19 & 4.31 & 16954 & 40.57 & 11 & 15.28 & 1 & & & & & & & \\
\hline Odontoceti & & & & & & & & 1 & 0.52 & 700 & 2.97 & 1 & 1.23 & \\
\hline Puffinus gravis & & & & & & & & 12 & 6.19 & 2388 & 10.13 & 4 & 4.94 & 5 \\
\hline Salpidae & 7 & 1.59 & 4 & 0.01 & 3 & 4.17 & & 7 & 3.61 & 8 & 0.03 & 3 & 3.70 & 9 \\
\hline Zenaida auriculata & 1 & 0.23 & 158 & 0.38 & 1 & 1.39 & & & & & & & & \\
\hline Others & 27 & 6.12 & 17116 & 40.96 & & & & 20 & 10.31 & 3096 & 13.14 & & & \\
\hline Total & 441 & 100 & 41792 & 100 & & & & 194 & 100 & 23564 & 100 & & & \\
\hline
\end{tabular}



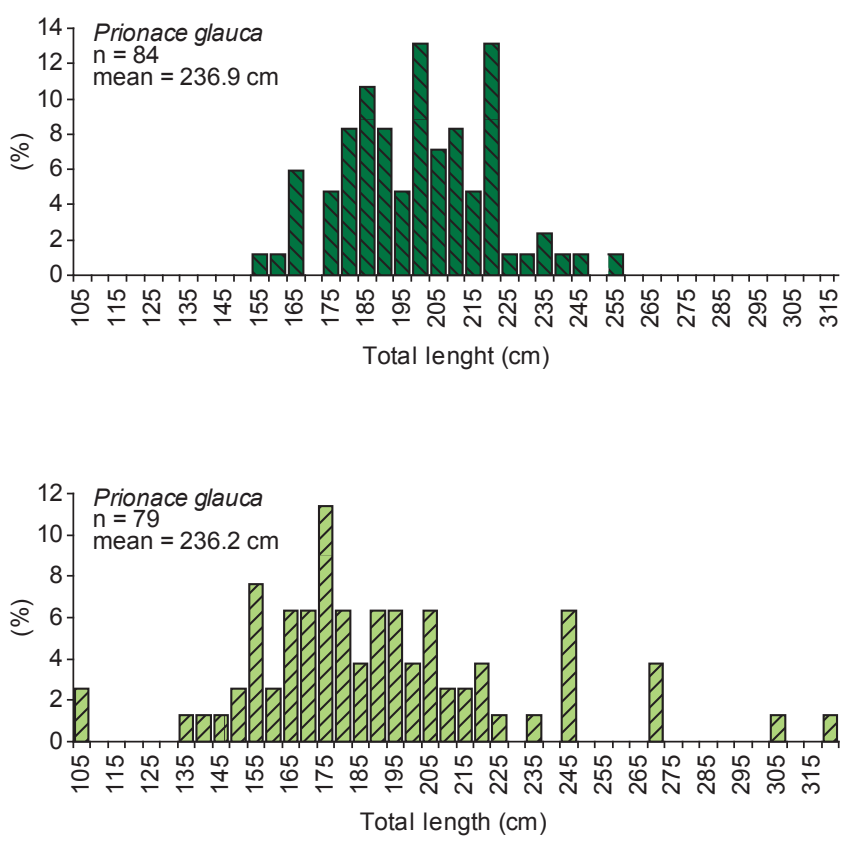

Figure 2. Total length of Prionace glauca (both sexes) for the southern and northeastern regions.

Figura 2. Comprimentos totais de Prionace glauca (ambos os sexos) para as regiões sul e nordeste.

and three others), compared to 25 taxa in the northeastern region (nine species of fishes, 13 cephalopods and three others). Diet in the northeastern region was less diverse and revealed a tendency toward stabilizing at twenty food items, whereas diet in the south indicates the beginning of stabilization at around 40 food items, with 70 analyzed stomachs (Figure 3). Stomach fullness was similar in both regions, revealing a prevalence of stomachs $25 \%$ full (Figure 4); empty stomachs represented 30 to $40 \%$ of the total number analyzed. The niche overlap of the MacArthur \& Levins Index between northeastern and southern regions was $\mathrm{O}_{\mathrm{jk}}=0.749$, i.e., just $7.49 \%$ of the diets were similar.

Anthropogenic material was often found in the stomachs, such as plastic bags, cardboard, bait box, wood, potato, onion, garlic, pineapple, peanuts, orange, apple, pear, chicken bones, wire, twine, and fishing hooks. It was estimated that about $5 \%$ of the blue sharks caught in Brazilian waters have at least one longline hook in their stomachs.

\section{Discussion}

Sexual maturity of female and male blue sharks is reached around $228 \mathrm{~cm} \mathrm{TL}$ and $225 \mathrm{~cm}$ TL, respectively (Hazin \& Lessa 2005), which means that most blue sharks in the present study were under the size of sexual maturity, $92.8 \%$ in the northeast, and $92.4 \%$ in the south. Despite this, most of the juveniles were relatively large and are believed to perform feeding habits similar to adults, once the body size is similar to the adults.

According to the IRI ranking and niche overlap, feeding habits are quite different for blue sharks in the northeastern and southern regions. Although most preys are cosmopolitan dwellers along the Brazilian coast, some are indicative of different water masses. For example, Alepisaurus ferox is a typical tropical/equatorial species and $A$. brevirostris is a subtropical and circumpolar species, but as they are similar in shape, they are important prey for the blue shark, especially A. ferox in the northeast.

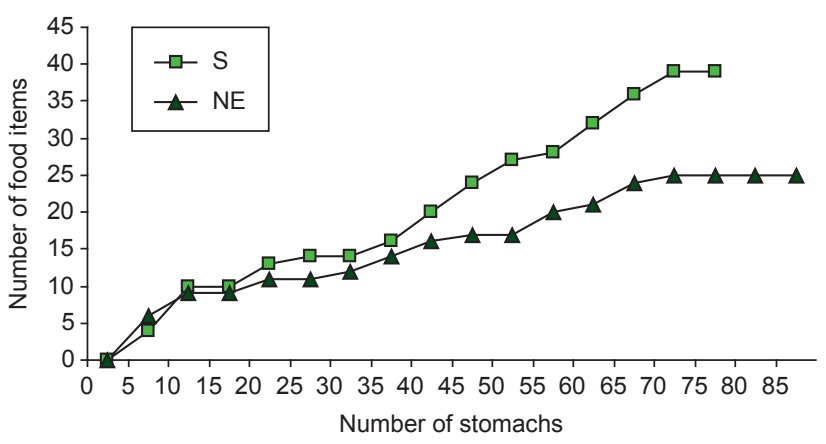

Figure 3. Number of food items in relation to the number of stomachs analyzed for Prionace glauca in the southern and northeastern regions of Brazil.

Figura 3. Número de itens alimentares em relação ao número de estômagos analisados para Prionace glauca nas regiões sul e nordeste do Brasil.

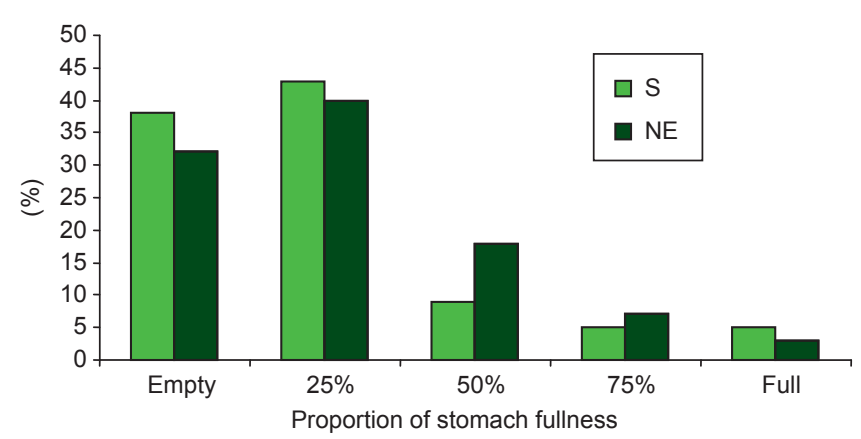

Figure 4. Percentage of stomach fullness proportions for Prionace glauca in the southern (S) and northeastern (NE) regions of Brazil.

Figura 4. Porcentagens das proporções de de repleção estomacal para Prionace glauca nas regiões sul (S) e nordeste (NE) do Brasil.

Among cephalopods, Illex argentinus is the most abundant species along the continental slope from $22^{\circ} \mathrm{S}$ to $54^{\circ} \mathrm{S}$ and is more abundant from $35^{\circ} \mathrm{S}$ to $52^{\circ} \mathrm{S}$ (Haimovici \& Perez 1990, Brunetti et al. 1991). Thus, I. argentinus is another important prey for the blue shark in the southern region. Hyaloteuthis pelagica is a common squid in the equatorial Atlantic, which composes the diet of sharks in the northeastern region alone. Histioteuthis spp. is a squid common to both regions; it performs expressive daily vertical migrations along thermoclines (Roper \& Young 1975) and is consequently preyed upon by blue sharks. Macnaughton et al. (1998) highlight the importance of cephalopods in the diet of sharks caught on the continental shelf of Ireland in tuna drift nets, including oceanic mid-water cephalopods such as the squid Histioteuthis sp. Thus, blue sharks make incursions below the thermocline to prey upon animals of low mobility, such as ammoniac squids (Histioteuhidae, Chiroteuthidae, Cranchiidae) and alepisaurids. According to Carey (1992), experiments in telemetry with the blue shark on the slope of the New York Bight revealed that the species leaves the surface and swims up and down through the thermocline, passing through large temperature changes while diving to depths as great as $600 \mathrm{~m}$. These incursions are repeated at one to three hours intervals, preying upon the vertical migrant octopus Alloposus mollis. Blue sharks are known to occur in waters ranging from 5.6 to $28{ }^{\circ} \mathrm{C}$ with temperature estimations based on associated catch rates, which vary considerably between the two study regions (Nakano \& Seki 2002). Strasburg (1958), reports that $99 \%$ of blue sharks in the Pacific are caught in water temperatures ranging from 5.6 to $18.9^{\circ} \mathrm{C}$. Hazin (1993), reports that blue sharks are vertically 
distributed in the adjacencies of the thermocline, which is relatively stable throughout the year, ranging from 15 to $25^{\circ} \mathrm{C}$ at depths of around $100 \mathrm{~m}$ in the northeastern region. In southern Brazil, the thermocline is close to the surface (between 30 and $50 \mathrm{~m}$ ) due to the South Atlantic Central Water (SACW) penetration into the continental shelf (Castello et al. 1990, Garcia 1997). The mesopelagic squids Chiroteuthis veranyi and Moroteuthis robsoni are the main prey items for the blue shark in waters in the extreme south of Brazil (Vaske Jr. \& Rincon Fo. 1998), which can be attributed to the cold SACW that allows mesopelagic squids to migrate to epipelagic layers, leading to their becoming more frequently preyed upon by blue sharks.

Empty stomachs are commonly found in sharks (Le Brasseur 1964, Harvey 1989, Hazin et al. 1994, Vaske Jr. \& Rincon Fo. 1998, Stevens 1973, Mcord \& Campana 2003), because they normally feed periodically upon large prey and swallow water when hooked, which increases the proportion of empty stomach and those $25 \%$ full found in overall samples. The blue shark clearly prefers large and slow-moving prey, because it is not a fast-swimming predator like other carcharhinids and lamnids. Its long thin body and heterocercal tail is not well-adapted to the pursuit of large fast-swimming prey, such as tuna and tuna-like species. The occurrence of chunks of large fast-swimming predators such as Thunnus sp., Tetrapturus pfluegeri and Xiphias gladius in the diet is explained by depredation of damaged specimens hooked on longlines. Two species of birds were also found: Puffinus gravis is a common open-sea seabird in the northeastern region; Zenaida auriculata a continental pigeon that also occur in the Fernando de Noronha archipelago, was found in very good condition in the stomach of a shark caught 120 miles off the coast. Seabirds such as Manx shearwaters (Puffinus puffinus) have also been found in the stomachs of blue sharks that have been observed harassing birds at the surface (Stevens 1973, Macnaughton et al. 1998). These birds probably dropped into the water and were swallowed after drowning.

Copulation takes place off southeastern Brazil mainly from December to February, whereas ovulation and fertilization occur off northeastern Brazil about three to four months later, mainly from April to June (Hazin et al. 2000, Hazin \& Lessa 2005). In the Gulf of Guinea, females in early pregnancy are found from June to August (Castro \& Mejuto 1995). During the cycle, blue sharks probably prey upon the local fauna in the thermocline, which is deeper in the northeastern region and closer to the surface (associated to the subtropical convergence) in the southern region.

The occurrence of anthropogenic material in the stomachs may reflect the increasing level of pollution in open waters and the excessive number of tuna longliners operating in the area, which leads the blue shark to a high probability of encounters with longline hooks.

\section{Acknowledgements}

The authors are grateful to CEPENE and CEPSUL (IBAMA), SECIRM (Inter-Ministerial Commission for Sea Resources) and CNPq (National Council of Scientific and Technological Development), which provided research grants. The authors are indebted to UNESP-CLP and the Department of Fishery and Aquaculture of the UFRPE - where the stomachs were examined - for logistical support. Tatiana Neves, Fabiano Peppes, and Patricia Mancini provided helpful assistance in sample collections in southern Brazil.

\section{References}

AMORIM, A.F., ARFELLI, C.A. \& BACILIERI, S. 2002. Shark data from Santos longliners fishery off southern Brazil (1971-2000). Col. Vol. Sci. Pap. ICCAT. 54(4):1341-1348.
AZEVEDO, V.G., KOTAS, J.E. \& SANTOS, S. 2003. Dinâmica da frota espinheleira de superfície atuante na região sudeste-sul do Brasil. In Dinâmica das frotas pesqueiras: análise das principais, pescarias comerciais do sudeste-sul do Brasil. (Cergole, M.C., Wongtschowski, C.L.D.B.L., eds.). Evoluir, São Paulo, p. 365-376.

BRUNETTI, N.E., IVANOVIC, M.L., LOUGE, E. \& CHRISTIANSEN, H.E. 1991. Reproductive biology and fecundity of two stocks of the squid (Illex argentinus). Publ. Com. Téc. Mix. Fr. Mar. 8(A):73-84.

CAREY, F.G. 1992. Through the thermocline and back again. Heat regulation in big fish. Oceanus. 35(3):79-85.

CASTELLO, J.P., DUARTE, A.K., MÖLLER O.O., NIENCHESKI, L.F.H., ODEBRECHT, C., WEISS, G., HABIAGA, R.P., BELLOTO, V.R., KITZMANN, D., SOUTO, C., SOUZA, R.B., CIOTTI, A.M., FILMANN, G. \& SCHWINGEL, P.R. 1990. On the importance of coastal and subantartic waters for the shelf ecosystems off Rio Grande do Sul. In II Simpósio de Ecossistemas da Costa Sul e Sudeste Brasileira: estrutura, função e manejo. (Watanabe, S., ed.). ACIESP. 74(1):112-129.

CASTRO, J.A. \& MEJUTO, J. 1995. Reproductive parameters of blue shark, Prionace glauca, and other sharks in the Gulf of Guinea. Mar. Fresh. Res. 46:967-973.

CLARKE, M.R. \& STEVENS, J.D. 1974. Cephalopods, blue sharks and migration. J. Mar. Biol. Assoc. U. K. 54:949-957.

COMPAGNO, L.J.V. 1984. FAO Species catalogue. FAO Fish. Synop. 125(4):251-655. (v. 4, part 2).

CORTÉS, E. 1999. Standardized diet compositions and trophic levels of sharks. ICES J. Mar. Sci. 56:707-717.

GARCIA, C.A.E. 1997. Subtropical convergence environments: the coast and sea in the southwestern Atlantic. Springer-Verlag, Berlin, p. 94-96. (cap. Physic Oceanogr.).

GUBANOV, Y.P. \& GRIGORYEV, V.N. 1975. Observations on the distribution and biology of the blue shark Prionace glauca (Carcharhinidae) of the Indian Ocean. J. Ichthyol. 15:37-43.

HAIMOVICI, M. \& PEREZ, J.A.A. 1990. Distribución y maduración sexual del calamar argentino, Illex argentinus (Castellanos, 1960) (Cephalopoda: Ommastrephidae), en el sur de Brasil. Sci. Mar. 54(2):179-1895.

HARVEY, J.T. 1989. Food habits, seasonal abundance, size, and sex of the blue hark, Prionace glauca, in Monterey bay, California. Calif. Fish Game. 75(1):33-44.

HAZIN, F.H.V. 1993. Fisheries-oceanographical study on tunas, billfishes and sharks in the southwestern equatorial Atlantic Ocean. Tese de Doutorado, Fishery University of Tokyo, Japan, $286 \mathrm{p}$.

HAZIN, F.H.V., LESSA, R.P. \& CHAMMAS, M. 1994. First observations on stomach contents of the blue shark, Prionace glauca, from southwestern equatorial Atlantic. Rev. Bras. Biol. 54(2):195-198.

HAZIN, F.H.V. \& LESSA, R.P. 2005. Synopsis of biological information available on blue shark, Prionace glauca, from the southwestern Atlantic ocean. Col. Vol. Sci. Pap. ICCAT. 58(3):1179-1187.

HAZIN, F.H.V., PINHEIRO, P.B. \& BROADHURST, M.K. 2000. Further notes on reproduction of the blue shark, Prionace glauca, and a postulated migratory pattern in the South Atlantic. Ciência e Cultura. 52(2):114-120.

International Union for Conservation of Nature - IUCN. 2008. Red list of threatened species. IUCN, Cambridge. www.iucnredlist.org. (último acesso em: 05/20/2009).

KREBS, C.J. 1989. Ecological methodology. Harper \& Row Publishers, New York, $654 \mathrm{p}$.

LE BRASSEUR, R. J. 1964. Stomach contents of the blue shark (Prionace glauca L.) taken in the Gulf of Alaska. J. Fish. Res. B. Can. 21:861-862.

MACNAUGHTON, R., ROGAN, E., HERNANDES-GARCIA, V. \& LORDAN, C. 1998. The importance of cephalopods in the diet of blue sharks (Prionace glauca) south and west of Ireland. ICES C. M. $7: 1-12$. 
MCCORD, M.E. \& CAMPANA, S.E. 2003. A quantitative assessment of the diet of the blue shark (Prionace glauca), off Nova Scotia, Canada. J. Northw. Atl. Fish. Sci. 32:57-63.

NAKANO, H. \& SEKI, M.P. 2002. Synopsis of biological data on the blue shark, Prionace glauca Linnaeus. Bull. Fish. Res., 6:18-55.

PINKAS, L., OLIPHANT, M.S. \& IVERSON, I.L.K. 1971. Food habits of albacore, bluefin tuna, and bonito in Californian waters. California Department of Fish and Game, Fish. Bull. 152:1-105.

ROPER, C.F.E. \& YOUNG, R.E. 1975. Vertical distribution of pelagic cephalopods. Smiths. Contrib. Zool. 209:1-51.

STEVENS, J.D. 1973. Stomach contents of the blue shark (Prionace glauca L.) off south-west England. J. Mar. Biol. Assoc. U. K. 53:357-361.
STRASBURG, D.W. 1958. Distribution, abundance and habits of pelagic sharks in the central. Pacific ocean. United States Fishery and Wildlife Service. Fish. Bull. 58:335-361.

TRICAS, T. C. 1979. Relationships of the blueshark, Prionace glauca and its prey species near Santa Catalina Island, California. Fish. Bull. 77(1):175-182.

VASKE, Jr., T. \& RINCÓN FO, G. 1998. Conteúdo estomacal dos tubarões azul (Prionace glauca) e anequim (Isurus oxyrinchus) em águas oceânicas no sul do Brasil. Rev. Brasil. Biol. 58(3):443-450.

Received 21/10/08

Revised 04/02/09

Accepted 01/07/09 